\title{
Selbst bei verdautem Mageninhalt lohnt DNA-Extraktion nach dem Tod
}

Untersuchungen des Mageninhalts lassen oft Rückschlüsse auf die letzten Lebensstunden von Verstorbenen zu. In einer Studie wurde die Effizienz von DNA-Extraktionen aus dem Mageninhalt getestet. Es sollte analysiert werden, wie gut sich DNA aus dem Mageninhalt Verstorbener für molekularbiologische Anwendungen eignen. Zu diesem Zweck wurde der Mageninhalt von 48 Obduktionsfällen untersucht und nach dem Verdauungsgrad in vier Grade unterteilt: Grad 1 unverdaut mit festen Bestandteilen, Grad 2 beginnend verdaut und verflüssigt, Grad 3 fortgeschritten verdaut und verflüssigt, Grad 4 $\checkmark$ vollständig verdaut und verflüssigt.

\section{Zunehmende Verdauung macht} Nachweis schwieriger

Mit dem Mericon Food Kit wurde aus einer Menge von jeweils zwei Gramm Mageninhalt DNA extrahiert. Die DNA-Ge- samtkonzentration im Extraktionsprodukt wurde fluorometrisch mit dem Qubit dsDNA-HS-Assay bestimmt. Mithilfe des QuantiPlex-Assay wurde die Konzentration humaner bzw. nicht-humaner DNA ermittelt. In 44 von $48 \mathrm{Ma}-$ geninhalten (92\%) wurde nicht-humane DNA im Mageninhalt extrahiert. In allen Fällen (100\%) konnte in den nicht bis wenig verdauten Mageninhalten nicht-humane DNA nachgewiesen werden. Bei den stärker verdauten Mageninhalten gelang dies in $80 \%$ der Fälle. Die Menge extrahierbarer nicht-humaner DNA nimmt mit zunehmendem Verdauungsgrad ab: So fielen im unverdauten Mageninhalt (Grad 1) im Median $790 \mathrm{ng} / \mu \mathrm{l}$ pro Gramm Ausgangsmaterial an. In beginnend und fortgeschritten verdautem $\mathrm{Ma}$ geninhalt fanden sich (Grad 2) im Median $380 \mathrm{ng} / \mu \mathrm{l} \mathrm{bzw}$. (Grad 3) $270 \mathrm{ng} / \mu \mathrm{l}$ nicht-humaner DNA. In praktisch voll- ständig verdautem Mageninhalt konnte kaum noch nicht-humane DNA nachgewiesen werden: Im Median $50 \mathrm{ng} / \mu \mathrm{l}$.

In Einzelfällen sei bei fortgeschrittenen oder quasi vollständig verdautem Mageninhalt keine Extraktion nicht-humaner DNA mehr möglich. Oft könne jedoch selbst bei praktisch vollständig verdautem Mageninhalt noch so viel nicht-humane DNA gewonnen werden, dass weitere molekularbiologische Spezifikationen möglich sind und einzelne Nahrungsbestandteile nachgewiesen werden können. Dadurch würden wertvolle Hinweise auf die Umstände der letzten Lebensstunden der Verstorbenen geliefert. In weiteren Studien müsste nun auch die Amplifizierbarkeit der extrahierbaren DNA betrachtet werden.

(Kathrin von Kieseritzky)

\section{Gewalt gegen Kinder}

\section{Verdacht auf Misshandlung: Bald Hotline für Ärzte von Ärzten}

Der Weg für eine Rund-um-die-Uhr-Kinderschutz-Hotline für Ärzte und Angehörige von Heilberufen ist so gut wie frei. Auf den letzten Drücker haben die Haushaltspolitiker der Union 1,35 Millionen Euro in den Haushalt 2016 des Familienministeriums einstellen lassen. Der soll am 19.11. beschlossen werden. Mit dem Geld soll vorerst für drei Jahre ein Beratungstelefon für Ärzte finanziert werden, die einen Verdacht auf Kindesmisshandlung hegen. Beraten sollen erfahrene Mediziner. Wie der Beschluss umgesetzt wird, steht noch nicht fest. Die Idee stammt vom Kinderund Jugendpsychiater Prof. Jörg Fegert. Ärzte hätten ohnehin Anspruch auf Beratung, wenn es um die Wahrung des Kin- deswohls gehe, sagte er zu Springer Medizin. Bislang leistet dies die Jugendhilfe der Kommunen. Das scheint nicht zu funktionieren. "Jugendhilfe und Ärzte sprechen jeweils eine andere Sprache und denken in anderen Zeiträumen", sagt Fegert.

\section{Berater sollten fachkundig sein}

Jugendämter sind nur werktags besetzt. Zudem hätten die Kinderschutz-Fachkräfte der Jugendämter nur selten Erfahrung mit Akutmedizin. "Die richtigen Schritte einzuleiten, erfordert Kenntnisse der Rechtsmedizin und des Systems der Kinder- und Jugendhilfe", umreisst Unionspolitiker Marcus Weinberg die Anforderungen an die künftigen Berater. Vorbild sei der Gift- notruf, wo auch in kurzer Zeit wichtige Entscheidungen getroffen werden müssten. Harte Zahlen zum Bedarf liegen nicht vor. "Das Projekt kann auch dazu dienen, den Bedarf erst aufzudecken", sagt Fegert. Immerhin: Die Evaluation des Kinderschutzgesetzes zeigte, dass ein kleiner Teil der Kinder- und Jugendärzte in Verdachtsfällen schon Kontakt zu Jugendämtern aufgenommen hat. Bei der Evaluation des Kinderschutzgesetzes wurden bisher ausschließlich niedergelassene Kinder- und Jugendärzte befragt. Der Rücklauf war wenig repräsentativ. $60 \%$ gaben an, den Beratungsanspruch zu kennen. (Anno Fricke)

www.aerztezeitung.de 